\title{
PENERAPAN MODEL POE2WE PADA PEMBELAJARAN KALOR UNTUK MENINGKATKAN PEMAHAMAN PESERTA DIDIK
}

\author{
Ina Rostiana \\ Program Pendidikan Fisika Fakultas Keguruan dan Ilmu Pendidikan \\ Universitas Siliwangi \\ Jln. Siliwangi No.24 Tasikmalaya \\ E-mail : inarostiana06@gmail.com
}

\begin{abstract}
Fisika merupakan bagian dari sains yang dianggap sebagai mata pelajaran membosankan dan sulit untuk dipahami. Maka dari itu, penelitian ini bertujuan untuk : (1) peserta didik mampu lebih memahami materi kalor. (2) mendeskripsikan model POE2WE dalam konsep kalor untuk meningkatkatkan pemahaman peserta didik. Salah satu model yang dapat digunakan oleh pendidik yaitu menggunakan model POE2WE (Prediction, Observation, Explanation, Elaboration, Write and Evaluation). Model ini diharapkan dapat membantu peserta didik lebih paham terhadap materi kalor. Penelitian ini menggunakan metode studi pustaka.Hasil penelitian menunjukan bahwa model POE2WE mampu meningkatkan pemahaman peserta didik dan menurut Nana (2018) menyatakan hasil tes pada konsep suhu dan kalor dengan tingkat pemahaman rata-rata sebesar $8 A=92,6 \%$ dan $8 B=92,3 \%$
\end{abstract}

Key words: Kalor, Model POE2WE.

\begin{abstract}
Abstrak - Physics is a part of science that is considered a boring subject and difficult to understand. Therefore, this study aims to: (1) students are able to better understand the heat material. (2) describe the POE2WE model in the concept of heat to increase students' understanding. One model that can be used by educators is to use the POE2WE (Prediction, Observation, Explanation, Elaboration, Write and Evaluation) model. This model is expected to help students better understand heat material. This study uses the literature study method. The results show that the POE2WE model can improve students' understanding and according to Nana (2018) states the test results on the concept of temperature and heat with an average level of understanding of $8 A=92,6 \%$ and $8 B=92,3 \%$
\end{abstract}

Kata kunci: Heat, Model POE2WE.

\section{PENDAHULUAN}

Kalor merupakan proses transfer energi dari suhu tinggi ke suhu rendah. Kebanyakan dari materi kalor peserta didik kurang mampu memahami materi yang dipelajari. Diharapkan Pendidik dapat menggunakan model pembelajaran sebagai salah satu metode penyampaian materi untuk meningkatkan pemahaman peserta didik. Model pembelajaran yang dapat digunakan salah satunya model POE2WE (Prediction, Observation, 
Explanation, Elaboration, Write and Evaluation).

Menurut Y. Astuti (dalam Depdiknas, 2006), mengatakan bahwa dalam proses belajar mengajar siswa berperan aktif dalam upaya menemukan pengetahuan, konsep, teori dan kesimpulan bukan merupakan upaya mengumpulkan informasi atau fakta. Agar proses tersebut terlaksana, diperlukan peran guru sebagai pengarah kegiatan belajar mengajar sehingga siswa tidak hanya memperoleh pengetahuan namun juga mampu membangun pengetahuan untuk dirinya sendiri, sehingga pembelajaran berpusat pada siswa bukan berpusat pada guru.

Pada kurikulum 2013 peserta didik dituntut lebih aktif dan kreatif. Dalam Nana, dkk bahwa pembelajaran kurikulum 2013 adalah pembelajaran kompetensi dengan memperkuat proses pembelajaran dan penilaian autentik untuk mencapai kompetensi sikap, pengetahuan dan keterampilan.

Selain itu peserta didik juga harus mengembiasakan diri untuk meningkatkan kemampuan literasi. Dari kemampuan literasi tersebut peserta didik dapat mencari dan mengembangkan informasi mengenai materi yang akan dipelajari. Sehingga peserta didik dapat memahami materi pelajaran untuk memecahkan suatu permasalahan.
Menurut Yuliati (2017) menyatakan literasi sains merupakan kemampuan untuk memahami sains, mengkomunikasikan sains, serta menerapkan kemampuan sains untuk memecahkan masalah.

Pada metode pembelajaran pendidik dapat melakukan strategi pembelajaran yang sesuai dengan kemampuan peserta didik.kemampuan peserta didik dalam memahami materi berbeda-beda, sehingga pendidik harus mampu mengani permasalahan peserta didik tersebut. dengan strategi yang sesuai peserta didik tersebut dapat memahami materi kalor.

Tujuan dari penelitian ini adalah peserta didik dapat memahami materi mengenai kalor dan pendidik dat menerapkan model pembelajaran POE2WE pada materi kalor.

\section{LANDASAN TEORI}

Metode pembelajaran fisika mengenai materi kalor yang digunakan dalam penelitian ini adalah model POE2WE. Menurut Nana (2018) menyatakan POE2WE merupakan salah satu model pembelajaran, pendidik dapat melakukan tahapan pada model POE2WE ini, yang pertama "Tahap prediction yaitu siswa membuat prediksi atau dugaan awal terhadap suatu permasalahan. Pendidik dapat mengajukan pertanyaan yang mendorong siswa untuk dapat membuat prediksi atau jawaban sementara dari suatu permasalahan. 
Tahap Observation yaitu untuk membuktikan prediksi yang telah di buat oleh siswa. Siswa diajak melakukan eksperimen berkaitan dengan masalah atau persoalan yang di temukan

Tahap Explanation atau menjelaskan yaitu siswa memberikan penjelasan terhadap hasil eksperimen yang telah dilakukan. Tahap Elaboration yaitu siswa membuat contoh atau menerapkan konsep dalam kehidupan seharihari. Tahap ini pendidik medorong siswa untuk menerapkan konsep baru dalam situasi baru sehingga siswa lebih memahami konsep yang di ajarkan guru. Tahap ini pengembangan dari pendekatan konstruktivistik.

Tahap write atau menulis yaitu melakukan komunikasi secara tertulis,merefleksikan pengetahuan dan gagasan yang dimiliki siswa. Dan yanng terakhir Tahap Evaluation yaitu evaluasi terhadap pengetahuan, keterampilan dan perubahan proses berfikir siswa."

Kalor (Q) merupakan proses perpindahan energi dari suhu tinggi ke suhu rendah. Satuan kalor adalah joule (J). 1 kalori $=4,184$ joule. Perpindahan kalor terbagi kedalam tiga bagian, yaitu konduksi, konveksi dan radiasi.

$$
\begin{aligned}
c & =\frac{\mathrm{Q}}{\mathrm{m} \Delta T} \\
Q & =\mathrm{mc} \Delta T
\end{aligned}
$$

Keterangan :

$\mathrm{Q}=$ banyaknya kalor yang diperlukan atau dilepaskan (J) $\mathrm{m}=$ massa benda $(\mathrm{kg})$
$\Delta T=$ perubahan suhu $\left({ }^{\circ} \mathrm{C}\right)$

$\mathrm{c}=$ kalor jenis suatu zat $\left(\mathrm{J} / \mathrm{kg}^{\circ} \mathrm{C}\right)$

\section{METODE PENELITIAN}

Metode penelitian yang telah dilakukan, peneliti menggunakan metode studi pustaka yaitu peneliti dapat membaca dari berbagai literature untuk menghasilkan data yang relevan menganai materi kalor.

\section{HASIL DAN PEMBAHASAN}

Berdasarkan data yang diperoleh dari Nana (2018), bahwa pemahaman peserta didik mengenai materi kalor yang dapat menjawab dengan benar yaitu kelas $8 \mathrm{~A}$ $81,2 \%$ kelas 8 B $83,7 \%$. Sedangkan pada tes setelah remidiasi pada kelas $8 \mathrm{~A}$ 92,6\% sedangkan kelas 8B 92,3\%. Sedangkan yang menjawab salah pada tes 2 kelas 8A 18,8\% kelas 8B 16,3\%, pada tes 3 yang menjawab salah kelas 8A 7,4\% kelas 8B 7,7\%.

Sehingga dengan adanya remediasi atau evaluasi tersebut peserta didik dapat meningkatkan pemahamannya mengenai materi kalor. Selain itu, dengan penerapan model POE2WE pendidik dapat memberikan tahapan pembelajaran Prediction, Observation, Explanation, Elaboration, Write and Evaluation di kelas pada peserta didik. Dari Nana (2018), hasil tes menunjukan pada konsep suhu dan kalor dengan tingkat pemahaman rata-rata sebesar $8 \mathrm{~A}=92,6$ $\%$ dan $8 \mathrm{~B}=92,3 \%$. Persentase 
kelayakan memberikan remediasi kepada peserta didik yang berarti sangat baik.

Pada model POE2WE ini, pendidik mampu memberikan tahapan pembelajaran dengan tahap pertama prediction, yaitu peserta didik dapat diajak memprediksi mengenai materi kalor, sehingga dengan prediksi tersebut, peserta didik dapat berpikir kritis. Selain itu, tahapan yang kedua Observation, setelah melakukan prediksi, peserta didik mampu melakukan ekperimen atau membuktikan dari materi yang telah di prediksi sebelumnya, dengan kegiatan eksperimen peserta didik dapat menangkap materi lebih cepat dikarenakan peserta didik dapat membuktikan langsung materi mengenai kalor. Di samping kegiatan ekperimen, pendidik dapat membimbing dan memberikan arahan jika ada peserta didik yang merasa kesulitan dalam melakukan eksperimen.

Tahap yang ketiga yaitu explanation, setelah melakukan ekperimen, peserta didik mampu menjelaskan hasil dari eksperimen tersebut, dari penjelasan tersebut peserta didik juga dapat mengembangkan kecakapan dalam berbicara di depan umum.

Tahap keempat yaitu elaboration, yaitu peserta didik mampu menerapkan materi kalor dalam kehidupan seharihari, pendidik mampu memberikan penjelasan juga mengenai manfaat pembelajaran materi kalor, sehingga peserta didik dapat menerapkan materi kalor tersebut dalam kehidupan seharihari.

Tahapan yang kelima write, pendidik mampu memberikan arahan kepada peserta didik misalnya menyuruh peserta didik membuat kesimpulan dari materi kalor yang telah dipelajari. Peserta didik mampu belajar memilih kata dan mampu mengekspresikan dirinya dengan kegiatan menulis tersebut.

Dan tahapan yang terakhir yaitu evaluation, pendidik mampu memberikan latihan soal ataupun tugas tambahan mengenai materi kalor, sehingga dengan adanya evaluari tersebut mampu mengukur kemampuan peserta didik dalam materi kalor. Jika ada peserta didik yang belum paham, pendidik mampu memberikan evaluasi tambahan atau remedial kepada peserta didik. sehingga peserta didik dapat belajar lagi karena ketika nilainya belum memenuhi syarat tuntas maka peserta didik akan berusaha untuk mencapai target yang diinginkan.

\section{PENUTUP}

\section{A. Kesimpulan}

Berdasarkan penelitian di atas dapat disimpulkan bahwa: 1) Peserta didik mampu memahami materi kalor dengan menggunakan 2) pada tahapan model POE2WE yaitu Prediction, pendidik memberikan prediksi mengenai materi kalor. Observation, pendidik 
memberikan contoh atau ekperimen mengenai materi kalor. Explanation, yaitu peserta didik mampu memberikan penjelasan mengenai materi yang telah diajarkan. Elaboration, yaitu siswa mampu menerapkan materi kalor pada kehidupan. Selanjutnya Write, siswa mampu merefleksikan pengetahuanya dengan menulis. Evaluation yaitu peserta didik mengevaluasi mengenai meteri yang telah dipelajari. 3) Menurut Nana (2018) menyatakan hasil tes pada konsep suhu dan kalor dengan tingkat pemahaman rata-rata sebesar $8 \mathrm{~A}=92,6$ $\%$ dan $8 \mathrm{~B}=92,3 \%$

\section{B. Saran}

Saran yang dapat disampaikan untuk pendidik dari peneliti sebaiknya pendidik dapat mengajak suasana pembelajaran lebih menyenangkan agar tidak membosankan. Sehingga, peserta didik mampu menikmati materi yang diajarkan. Selain itu pendidik sebaiknya dapat lebih kreatif dalam menyampaikan materi pembelajaran menggunakan strategi yang sesuai dengan potendi peserta didik sehingga peserta didik mudah paham, lebih aktif serta kreatif.

\section{Ucapan Terima Kasih}

Saya sangat berterima kasih kepada Dr. Nana, M.Pd yang telah memberikan arahan serta bimbingan dalam menyelesaikan jurnal ini. Selain itu penulis juga ucapkan terima kasih kepada rekan-rekan yang telah membantu.

\section{REFERENCES}

[1] Astuti, Y, dkk. (2013). Pengembangan Lembar Kerja Siswa (LKS) Berbasis Pendekatan Inkuiri Terbimbing Dalam Pembelajaran Kooperatif Pada Materi Kalor. JPII. Hal 1.

[2] Depdiknas. (2006). Kurikulum 2004, Standar Kompetendi Mata Pelajaran IPA Sekolah Menengah Pertama dan Madrasah Tsanawiya. Jakarta: Direktorat Jendral Pendidikan Dasar dan Menengah Umum.

[3] Nana. (2018). Implementasi Model POE2WE Dengan Pendekatan Saintifik Dalam Pembelajaran Gerak Lurus di SMA. SNPS. 19.

[4] Nana. (2018). Penggunaan Pendekatan Konflik Kognitif Untuk Remediasi Miskonsepsi Pembelajaran Duhu Dan Kalor. SNPS.

[5] Nana., Sajidan., Akhyar. M., dan Rochsantiningsih,

D. (2013). Pengembangan Pembelajaran Fisika SMA Melalui Elaboration Write And Evaluation (EWE) dalam Kurikulum 2013. Surakarta. Universitas Sebelas Maret. Jurnal FKIP UNS. Hal 1-8.

[6] Nana. (2018). Model Prediction, Observation, Explanation, Elaboration, Write dan Evaluation (POE2WE) Aternatif Pembelajaran Fisika di Era Revolusi Industri 4.0. 
[7] Yuliati, Yuyu. (2017). Literasi Sains

Dalam Pembelajaran IPA. ISSN. 3(2) 